\title{
PARSEE RELIGIOUS CEREMONIAL OBJECTS IN THE UNITED STATES NATIONAL MUSEUM. ${ }^{1}$
}

\author{
By I. M. Casanowicz, \\ Assistant Curator, Division of Old World Archeology, United States National \\ Museum.
}

\section{INTRODUCTION.}

THE PARSEES.

The Parsees are the descendants of the ancient Persians, who, at the overthrow of their country by the Arabs in 641 A. D., remained faithful to Zoroastrianism, which was, for centuries previous to the Mohammedan conquest, the state and national religion of Persia. They derive their name of Parsees from the province of Pars or Fars, broadly employed for Persia in general. According to the census of 1911 the number of Parsees in India, including Aden, the Andaman Islands, and Ceylon, the Straits Settlements, China, and Japan, amounted to 100,499 , of whom 80,980 belonged to the Bombay Presidency. ${ }^{2}$ About 10,000 are scattered in their former homeland of Persia, mainly in Yezd and Kerman, where they are known by the name of Gebers, Guebers, or Gabars, derived by some from the Arabic Kafir, infidel.

zoroaster (avesta, zarathushtra; pahlavi texts, zartusht; modern persian, ZATDUSHT).

The religious beliefs and practices of the Parsees are based on the teachings of Zoroaster, the Prophet of the ancient Iranians; that is, those Aryans who at an unknown early date separated from the AryoIndians and spread from their old seats on the high plateau north of the Hindu Kush westward into Media and Persia on the great plateau between the plain of the Tigris in the west and the valley of the Indus in the east, the Caspian Sea and the Turanian desert in

\footnotetext{
$1 \mathrm{~A}$ brief description of part of the collection described in this paper appeared in the American Anthropologist, new series, vol. 5, 1903, pages 71-75, with 2 plates. Since then additions have been made to the collection, and as the article in the American Anthropologist is, moreover, not accessible to the general public, it was deemed feasible to give here a description of the enlarged collection with a fuller exposition of the religious tenets and rites of the Parsees.

2 James Hastings, Encyclopaedia of Religion and Ethics, vol. 9, p. 641.
} 
the north, and the Persian Gulf and the Indian Ocean in the south, surrounded on all sides by high mountain ranges, with a great salt desert in the center.

There are few authentic data about Zoroaster and his life. Concerning the age in which he lived there is wide diversity. Greek writers assigned him dates ranging between $6,500 \mathrm{~B}$. C. and 2,000 B. C., while some native sources and many modern scholars place him in the seventh century B. C. But the fact that by the sixth century B. C. Zoroastrianism had taken root in Persia, where it did not originate, as evidenced from the Behistun inscription of Darius Hystaspis (521-485 B. C.), which show him a worshiper of AhuraMazda, the supreme god of the Zoroastrian faith, and that it was well known to the classical authors from the sixth century on as the established religion at least of Media, would seem to accord best with the date of about 1,000 B. C., assumed by some scholars. The question of the birthplace of Zoroaster is also a subject of dispute, but western Iran, probably Atropatene, the mountainous district of ancient Media, corresponding nearly to the modern province of Azerbaijan in Persia, is commonly believed to be the region in which he arose. Tradition is quite in accord that Bactria in Eastern Iran, about the modern district of Balkh in Afghanistan, was the stage of Zoroaster's life and work.

Legend made of Zoroaster, as of other great religious teachers, a glorified and supernatural man. He was born in a miraculous way by immaculate conception, his soul having been kept in the sacred Haoma plant, till God's glory had purified his mother's body. At his birth all creation laughed with joy, while the evil demons fled aghast. When grown he was conducted by an archangel into the presence of God and in glory unutterable received divine revelations. After seven visions he was tempted by Angra-Mainyu (Ahriman), the Evil One, who, foreseeing the discomfiture he and his creatures were to suffer at Zoroaster's hands, first sent demon emissaries to kill him, but Zoroaster routed him by reciting the confession of faith, not to speak of rocks as big as houses that he had ready to pelt the devils with, defiantly declaring his purpose to destroy the fiends' creation. Angra-Mainyu thereupon offered him vast possessions and earthly dominion if he renounced the good religion (daena). But Zoroaster rejects the offer and declares that he will put the devils to flight with the apparatus of worship and the holy words. Thereupon the whole host, with cries of terror, precipitately flee down to the world of darkness.

What with some plausibility can be gathered from Zoroaster's own words and the earliest parts of the Zoroastrian scriptures, is that he was a man of good birth, belonging to the noble family of Spitama, 
and pure nature, who arose as a prophet and reformer of the old religion of the Iranians. At first his preaching met with much opposition and for years was without effect. But at last he succeeded in winning the king Hystaspes (Vishtap, Gushtap, not to be confounded with Hystaspes, the father of Darius) for his teaching, and with his aid converted by force in religious warfare the whole kingdom. At the age of 77 the aged warrior-prophet fell in one of these religious wars, while fighting against the fierce Turanians-says tradition. (Plate 1.)

THE SACRED Literature OF the parsees.

The oldest and original Zoroastrian literature goes under the general name of Avesta or Zend Avesta, which is rendered, "text" or "law" and commentary. It consists of the following divisions:

1. Yasna, the chief liturgical work and the oldest and most sacred part of the Avesta, including as it does the Gathas, hymns or psalms composed in an older dialect, some of which may have been composed by Zoroaster himself.

2. Tisparad, containing minor litanies, invocations to the various chiefs of the spiritual and terrestrial creation.

3. Yashts, invocations and hymns to the ancient Iranian divinities and heroes.

4. Khorda Avesta, or Little Avesta, comprising minor liturgicai texts, as the Nyaishes and Gahs, or the five daily prayers, the Afringans, or benedictions, etc., a kind of extract from the Avesta for laymen.

5. Vendidad, a code of religious and civil laws and precepts, a kind of Zoroastrian Pentateuch. ${ }^{3}$

Besides the Avesta scriptures, the language of which is akin to Sanskrit, the Parsee religious literature includes many works of a later date written in other languages, chiefly in Pahlavi. Among these are the Dinkard, the Bundahish, the historical account of the reformer-king Ardeshir, the vision of Arda Viraf in his journey through heaven and hell, a crude forerunner of Dante, and his Divina Commedia, etc.

ZOROASTRIAN THEOLOGY.

The supreme figure in Zoroastrianism is Ormuzd (Ahura-Mazda, "Wise Spirit," properly "Lord Wisdom"), the all-wise Lord, the God, who made heaven and earth and all that is therein, who gov-

${ }^{3}$ The present Avesta, which equals perhaps one-tenth of the Bible in extent, is believed to be but a small remnant of the original Zoroastrian sacred literature which was lost during the invasions of Persia by Alexander the Great (330 B. C.) and the Arabs (641 A. D.). According to the Arabian chronicler Tabari (died 923 A. D.) the Persian sacred scriptures were inscribed on 12,000 cowhides, and Hermippus, a Greek philosopher of the third century B. C., credits Zoroaster with the composition of 2,000,000 verses. 
erns everything with wisdom, righteousness, and goodness. Associated with him in the government of the world as his ministers are the Amshaspands (Amesha Spentas, "Immortal Holy Ones") : 1, Vohu Mano, good mind (the good principle, the idea of good that works in man, inclining him to what is good); 2, Asha, right (as conformity to the moral law and order); 3, Kshathra, the wishedfor kingdom (the Kingdom of God) ; 4, Armaiti, devotion (humble piety, reverence for the Divine) ; 5 , Haurvatat, welfare or perfection; and 6, Amertat, immortality. With these six, to make up the sacred seven, Sraosha, the genius of obedience, of "faithful hearing," is sometimes joined. They were at first mere attributes of God, or personified qualities and ideals of human character in the likeness of God; later certain specified parts of the world were put under their care; they were also assigned to different days and months, and each has a peculiar flower and color.

Besides the Amshaspands, who are termed the "children" of Ormuzd, or may be designated as archangels, the Avesta mentions some minor spiritual beings of the celestial hierarchy, such as the Yazatas (modern Izads), "worshipful or holy ones," ordinary angels; the Fravashis, protecting spirits, who help men in battle and accompany souls to the next world, and some mere abstractions, as Arshtat, watchfulness; Parendi, riches; Ashi, rectitude, etc.

Over against the realm of law and righteousness (asha), ruled by Ormuzd and his beneficent ministering spirits, is the sphere of the Lie (druj) and wickedness, dominated by Ahriman (Angra-Mainyu, "enemy spirit") at the head of the daevas, a body of malevolent and harmful powers. The relation of the opposing powers is variously represented in the different parts of the Zoroastrian scriptures. In the earlier Avesta (the Gathas) two primeval principles or causes of light and darkness, of life and death, of good and evil, personified in Spenta-Mainyu, the Holy Spirit of Ahura-Mazda, and AngraMainyu, respectively, are assumed, both being subordinate to and united in Ahura-Mazda. As they met they produced life and unlife, determining how at last there should be for the wicked the worst state, and for the righteous the "best mind." Zoroaster is made to say: "In the beginning there was a pair of twins, two spirits, each of a peculiar activity. These are the good and the base in thought, word, and deed. Choose one of these two spirits. Be good, not base. When the two spirits came together at the first to make life and death (not life) and to determine how the world at the last shall be for the wicked the worst life, for the holy the best mental state." In the younger Avesta (especially in the Bundahish) the distinction between the Holy Spirit and God is not preserved, both being identified, so that the opposition thenceforth stands between Ahriman and 
Ormuzd, and the conflict between them is extended from the moral sphere-the antithesis of good and evil as a fact in human life-to the physical realm. The ethical dualism hardened into a theological dualism. Over against Ormuzd stands Ahriman as an evil being of supernatural power at the head of the host of malevolent spirits, the cause of all that is evil and noxious in the world. Each of the amshaspands has for an opponent some archfiend (Akemmano, Andra, Saurva, Taro-Maiti, Tauru, Zairirica, and Aeshma (=Asmodeus, Tobit iii, 8 ; vi, 15). Below these stand the daevas, drujes, pairikas (peris), yatus, etc. Unceasing warfare goes on between these opposite powers. Ormuzd makes; Ahriman mars. The one dwells in endless light, the other in eternal darkness. To Ahriman are attributed the creation of all evil things. He created the killing cold of winter and the intemperate heat; serpents, locusts, ants, rapine, and lust; magic and witchcraft; pride, doubt, and unbelief; evil spirits, demons, and men of devilish character, beasts of prey and noxious vermin; floods and droughts; and the nine hundred and ninety-nine diseases the flesh is heir to are Ahriman's inventions.

The dualism implied in the Zoroastrian doctrine is saved from being a dyo-theism in so far as Ahriman is never the equal of Ormuzd.

Ahriman is neither omniscent nor almighty. He possesses only "backward knowledge"; he can not foresee. Hence, he is always too late in his machinations. Moreover, Ormuzd's limitation of power is merely temporary. Ahriman is coeval with Ormuzd but not coeternal. His doom is fixed. At the last judgment his creatures will perish and he himself will be banished from the regenerated earth. ${ }^{4}$

The Parsees protest against the imputation of dualism to their theological system. The primeval principles of good and evil (Vohumano and Akemmano, or Spenta-Mainyu and Angra-Mainyu), the Parsees claim, were, though opposed to each other, united in every existing being, even in Ahura-Mazda himself, and by their union produced the world of material things and of spiritual existences, while the Dastoor (high priest) Rastamji declares: "By angra-mainyu nothing is meant but man's evil spirit or thought. Man receives from Ahura-Mazda the gifts of superior powers, abuses

4 "The dualism of Zoroastrianism is an attempt to account for the evil of the present world, physical as well as moral, upon the premises of an ethical theism which can not admit that God is the author of any kind of evil. But because God is almighty as well as perfectly good, it can as little admit that evil, even in hell, is a permanent factor in the universe. The Zoroastrian theologians were concerned with the solution of the ethical problem rather than with the remoter problem which their solution raised. The evil spirit appears on the scene like a diabolus ex machina; whether he was eternal they do not seem to have asked, nor would they probably have been much disturbed if their logic had carried them to that conclusion, for since they did not define God metaphysically as the infinite and eternal, but as the good, an eternal devil would not thereby become God." (George Foot Moore, History of Religions, New York, 1913, vol. 1, p. 405.) 
them, and by abusing causes all moral and physical disturbances in himself and in the condition of the world he lives in." ${ }_{5}$ There is no question that the modern Parsees are monotheists.

Zoroastrianism is a religion of struggle and exertion. The cardinal doctrine that the world is a great battle field, on which beneficient powers ceaselessly contend with baleful forces is one of the hinges on which the entire system of Zoroastrian ethics turns. Man is not a passive spectator of this war on whose issue his fortune in time and eternity depends, but a combatant in the thick of the fight. Every man, being treated as a free agent, is by his own choice arrayed under one banner or the other, contending for the good world or the bad.

The moral teachings of Zoroaster are summed up in the triad: good thoughts, good words, good deeds (humata, hukhta, hvarshta; contrast: dushmata, duzhukhta, duzhvarshta). Character lies not in overt act alone, but in the inner springs of conduct. The virtues inculcated may be comprised in general terms as purity alike of body and soul, uprightness, humility, obedience, peaceableness, charity, and benevolence. In addition to these good qualities particular stress is laid upon truthfulness and the faithful keeping of one's word and pledge. "Never break an agreement, O Spitama, neither one that you make with a wicked man nor with an upright man of your own religion; for an agreement holds with both wicked and upright." Next to falsehood and deceit making debts is to be shunned, for that leads to lying and fraud. ${ }^{6}$

The tilling of the soil, the reclamation of waste land by rooting out weeds and thorns, and extending irrigation to make grain and fruits grow is part of practical religion. "Who makes glad the earth? He who plants the most grain, grass, and fruit trees, who brings water to a field where there is none and draws it off where there is too much. . . . How is the Mazdaean religion nourished? By zealously sowing grain. He who sows grain sows good. . ." The useful animals, especially cattle and dogs, are to be kindly treated, well fed and cared for; cruelty and neglect are grave sins, wanton killing of cattle a crime. On the other hand, the destruction of beasts of prey and noxious vermin is a highly meritorious act.

5 Rastamji Edulji Dastoor Peshotan, Zerathushtra and Zarathushtrianism in the Avesta. Leipzig, 1906, p. 159; compare also Dosabhai Framji Karaka, History of the Parsis, London, vol. 2, p. 187; Martin Haug, Essays on the Sacred Language, Writings, and Religion of the Parsees, Bombay, 1862, p. 258.

"Compare Herodotus, book 1, $\$ 136$ and 138: "Beginning with the age of 5 years to 20 , they [the Persians] instruct their soins in three things: to ride, to use the bow, and to speak truth. . . . To tell a lie is considered by them the greatest disgrace; next to that, to be in debt, and this for many reasons, but especially because they think that one who is in debt must of necessity tell lies." 
Zoroastrianism did not ignore the body for the elevation of the soul. Physical culture was extolled, and it allowed generally a whole-souled enjoyment of life. Wealth and a large family are signs of virtue. "He who has children is far better than he who is childless; he who has riches is far better than he who has none. . . ." ?

The Parsees, constituting one of the smallest religious communities in the world, occupy a most prominent place among the several nationalties and religious sects of India, and exemplify in their life the true worth of the teachings of the great Prophet of Iran. They uphold the best of the tenets of the old faith with regard to religious observations. They are distinguished by temperance, purity of life, energy, enterprise, and capacity, and their reputation for benevolence and generosity toward all men is world-wide.

THE HEREAFTER, OR ESCHATOLOGY IN ZOROASTRIAN THEOLOGY.

God's righteous rule involves the idea of judgment and retribution, and Zoroastrian eschatology provides a judgment both for the individual and for the world. The judgment of individuals takes place at death, in which each man's destiny is determined by his religion and by his thoughts, words, and deeds in this life. After death the soul lingers three days and three nights near the body. During these intervening days the soul of the pious tastes "as much of felicity and joy as the entire living world can taste," and the soul of the wicked tastes "as much of misery as the entire living world can taste." On the fourth day at dawn the soul sets out on its journey to the place of judgment at the chinvat bridge. To the righteous comes a perfumed breeze wafted as it were from the south. while the wicked is struck by a cold blast as out of the demonic north, laden with foul stench. At the bridge Mithra, Sraosha, and Rashnu sit in judgment. ${ }^{8}$ Rashnu weighs the merits and demerits of the departed on an "undeceiving" golden scale, and his fate is decided according to the result of the weighing, whether the good works or the bad ones tipped the scales. Thereupon the soul has to cross the chinvat bridge, which is spanning the abyss of hell. To the good soul it appears to be nine spear-lengths, or even a parasang (between three and four miles) wide, lead by a fair maiden-the

${ }^{7}$ Zarathustrian doctrine is the first serious attempt to conform material interests and duties with the spiritual needs and longings of mankind, and to reconcile the temporal with the eternal, by regarding the former as reflecting and preparing for the latter. The religious root-idea of Zarathushtrism, when first distinctly expressed, which, as history shows, has not remained fruitless, is that the life of the pious is a sacred labor and struggie, constantly directed against the evil and impure in what we are wont to distinguish as the world of nature and that of the spirit, in order that both may at last be thoroughly purified-in short, that every pious man, according to his ability, is a fellow-worker with God." (C. P. Tiele, Elements of the Science of Religion, Edinburgh and London, 1897, vol. 1, p. 192.)

${ }^{8}$ Parallel to Minos, Aeacus, and Rhadamanthus, the three judges of the dead, in Greek mythology.

20107-22-Proc. N. M. vol. $61--12$ 
embodiment of his good deeds and pious observances, and guided by the good dogs, who keep watch over the bridge. Through the three forecourts of good thoughts, good words, good deeds the soul passes into the "infinite light," or "light eternal" (Garonmana, "house of songs"), the abode of Ahura-Mazda with the archangels and the spirits of the just, where it is regaled with angels' food and set on a richly adorned throne. "Forever and everlasting they remain in all glory with the angels of the spiritual existences eternally."

Very different is the lot of the wicked. A demon lassoes his soul with his evil noose and drags him to the bridge, where Rashnu with his balances detects all his wickedness. His evil ways confront him in a foul hag whose ugliness is the expression of his character. He finds no helper, becomes frightened on the hairbroad bridge and tumbles down into the abyss. Through the vestibules of evil thoughts, evil words, evil deeds he arrives in the "infinite darkness," the "home of the Lie" ( $d_{m i j)}$, where the wicked dead surround him, the demons mock him, and Angra-Mainyu bids bring him loathsome and poisonous food: "And until resurrection he must be in hell in much misery and torments of many kinds." If the good deeds are equal to the bad ones he goes to the place called "equilibrium" (Hamestakan). The suffering here is slight, being only a change from cold to heat, inclement cold and burdensome heat following one after the other.

But hell is not eternal, and the bliss of souls in heaven and their torments in hell are not the final state of mankind. When the present world age is at an end there will be a great assize and a general judgment for all mankind. According to Zoroastrian cosmic chronology the whole drama of the world will be played out in a cycle of 12,000 years, divided into four periods of 3,000 years each. The first 3,000 years is the period of purely spiritual existences, as models of the future types of things. In the second period Ormuzd creates the material world. In the third Ahriman breaks into the creation of God. This is the age of human history characterized by the conflict between the rival powers of good and evil. At the beginning of the fourth period (anno mundi 9,000) Zoroaster appears, and at its close the great consummation begins. Saoshyant, the Savior, born miraculously of a pure maiden from the seed of Zoroaster which was hidden for thousands of years in the Seistan lake, in which she bathes, will appear, and all the dead will be raised, their bodies being reconstituted of their original materials. The risen dead will be assembled in one place and will know one another; the deeds of all will be manifest. Then the righteous and the wicked will be separated, the former going to heaven, while the latter are cast into hell to be punished in the body for three days, certain monsters of iniquity being subjected to exemplary sufferings. When this 
is over, the fire will melt the metal in the mountains till it overpours the whole world and makes it pure. To the righteous it will be like warm milk; to the wicked it will be like molten metal. Saoshyant then sacrifices the ox Hadhayous, and of his marrow and the juice of the Haoma is prepared the ambrosia which is given to the righteous as the food of immortality. All men become of one speech. Those who died old are restored to the age of forty, and if young to that of fifteen. ${ }^{9}$ Ahriman and his hordes of evil spirits will be conquered and slain, or driven unresisting into outer darkness. Hell itself is purified by the molten metal and added to the earth. And in this enlarged world, where there will be no more ice and no more mountains, which had been created by the evil one, men are to be immortal, and to live forever united with their families and relations, but without further offspring, in pure and peaceful bliss. ${ }^{10}$

\section{THE COLLECTION.}

1. Fire urn.-Brass, nickel-plated. The Zoroastrian ritual consists mainly in the tending of the sacred fire and in the offering of Haoma. On account of the former part of the worship the Zoroastrians are frequently denominated "fire worshipers." The Parsees reject this imputation with indignation. They pay reverence, not worship, to fire as bearing by reason of its brightness, activity, purity, and incorruptibility the most perfect resemblance to the nature and perfections of the supreme God, and therefore as his most adequate symbol. All the elements, as the pure creatures of Ahura-Mazda, are invested by the Zoroastrians with sanctity, but fire especially was considered as the earthly form of the heavenly light, the eternal, infinite, divine, the first creature of Ahura-Mazda, and in the Avestan scriptures,

- According to another version, vegetarians are raised young, and the eaters of flesh as of middle age.

${ }^{10}$ Mohammedan eschatology has borrowed much from the Zoroastrian. The conscience of the departed is in the Mohammedan version personated in a male figure in place of the female of Zoroaster's system. "To the good a man with beautiful face comes, elegantly dressed and perfumed, and says: 'Be joyful in that which made thee so; this is the day which was promised thee.' Then the dead person says to him: 'Who art thou, for thy face is perfectly beautiful?' And the man replies: 'I am thy good deeds.' To the wicked a man with a hideous countenance comes, shockingly dressed and of a vile smell, and says: 'Be joyful in that which makes thee miserable, for this is the day which was promised thee' 'Then the dead man says: 'Who art thou? Thy face is hideous and brings wickedness.' He says: 'I am thy impure deeds.', The balance (mizan) is held by the angel Gabriel and is so vast in size that its two scales, one of which hangs over paradise and the other over hell, are capacious enough to contain both heaven and earth. The bridge which is laid over hell, and named by the Mohammedans Cirat (properly, road, path), is finer than a hair and sharper than the edge of a razor and beset on each side with briars and hooked thorns. The good will pass with wonderful ease and swiftness, like lightning or the wind, Mohammed leading the way, while the wicked will miss their footing and fall down into hell which is gaping beneath them. (T. P. Hugh, Dictionary of Islam, 1885, pp. 79, 80, 543, and 544.) The bridge of separation has also a parallel in the log over which the American Indian has to come to get to the happy hunting grounds. If an Indian has been virtuous (that is, brave) the log lets him over, but otherwise he can not pass over it, but slips into the foul swamp never to emerge. 
called his son. "I sacrifice to thee, Fire, son of Ormuzd, and to all fires and all waters and to all plants, for they are all made by God." The Parsee temple (dar-i-mihr or agiaris) is divided into two parts: (1) the adaran, or place of fire, is a small domed room where the fire is kept burning in a metal urn resting on a stone stool (adasht), with a metal tray hanging from the dome $(t a j) ;(2)$ the izishu-gah, a large quadrangular room, divided by small channels (pavis), which is used for the celebration of ceremonies. According to the quality of the fire kept within, three grades of temples are distinguished: 1, Attash-dagdah, in which the ordinary fire preserved in a fire temple or even in houses and used in sacred ceremonies is kept; it may be touched both by priests and laymen; 2, Attash-adaran. The consecration of the fire requires great ceremonies; the utmost care is taken in watching it and keeping it perpetually burning; it may not be touched by any one but by priests; 3, Attash-bahran, the highest of all. The consecration of the fire entails heavy expenses and a long series of ritual for a year or more. The sacred fire is constantly watched by priests who have undergone the highest purifications. Its extinction would be regarded by the Parsees as a great calamity. Non-Zoroastrians are excluded from any fire temple.

The fire in the fire temple is purified in the following manner: Over a fire taken from various places of manufacture, to which, if possible, fire caused by lightning is added, a perforated metal tray containing small chips of fragrant sandal-wood is held until the chips are kindled by the heat. After a new fire is in this manner produced from the impure one, the latter is taken away, dispensed, and extinguished. Again, by means of the heat of this first new fire, another bundle of sandal-wood is ignited, and another fire is produced from it, and the first new fire is then taken way, dispersed, and extinguished. Each of the new fires is treated in the same manner until the ninth is reached, which, "being derived from the impure one through seven intermediate fires, more and more distants from the original impurity, represents the fire in its native purity." The fire in the temple is guarded from every kind of pollution; is fed with scrupulously selected wood (the Parsees in Bombay use sandalwood); the priest wears a thick veil, called padan, over his nose and mouth that his breath may not fall on the fire, his hands are encased in long gauntlets and the wood is handled with tongs. Five times a day, at the canonical hours (gahs), the priest cleans the room, washes the stone stools on which the fire urn rests, and puts fresh wood on the fire. Height, $13 \frac{1}{4}$ inches; diameters, $11 \frac{1}{2}$ and $7 \frac{1}{2}$ inches.-Bombay, India. (Plate 2, fig. 2, Cat. No. 216051, U.S.N.M.) ${ }^{11}$

${ }^{11}$ Fire altars, not necessarily in temples, were erected all over ancient Iran. Eariy reliefs and coins show the king standing before a fire altar under the open sky. But from the Achaemenian times on there were shrines in which the sacred flre was kept burning as at present. 
2. Fire ladle.-Brass, nickel-plated. The sacred fire and all that is connected with it must not come into contact with anything that may defile it. A ladle is therefore used for putting wood chips into the fire urn. Length, $13 \frac{1}{2}$ inches.-Bombay, India. (Plate 2, fig. 1, Cat. No. 216053, U.S.N.M.)

3. Fire tongs.-Brass, nickel-plated. Used for picking up the wood chips of the sacred fire which would be defiled if touched with the hands. Length, $13 \frac{1}{2}$ inches.-Bombay, India. (Plate 2, fig. 3, Cat. No. 216052, U.S.N.M.)

4. Sprigs of the Haoma Plant.-The Haoma (Sanskrit, soma, Pahlavi and Persian, hom), also called moon-plant and swallowwood, of the milkweed family, Sacrostemma brevistigma (Asclepias $a c i d a)$. To the juice expressed from its stems were attributed inspiring and healing properties, and it played an important part in the ritual and sacrifices of ancient India. It was personified and deified and worshiped as a god by the Hindus. In the Parsee ritual the haoma is one of the offerings made in the service of the Yasna, the principal of Zoroastrian liturgy, which is recited or chanted by two priests, known as the Zaoti and Rathvi, before the sacred fire. The twigs of the secred plant are washed and purified while reciting a prayer, then laid aside in a metal box for at least thirteen months and thirteen days before using in the ceremony. Under elaborate ceremonies the twigs are pounded in a mortar, the expressed juice is mixed with milk and holy water and strained. The draft thus obtained concentrates in itself all the virtues of plants, animals, and the waters. It is drunk sacramentally by the priests in the course of the service, and is administered to the dying as a "draft of immortality." The "green haoma" of this world is a type of the "white haoma" (haoma-i-saphid) of the gaokorena-tree, the emblem of immortality. In addition to the haoma the pomegranate and the barsom (Avesta, baresman) are used in the ceremony. The barsom consists of twigs or sprays of a certain plant or, where these are not obtainable, as in winter, of brass rods, from five to thirty-five, tied in a bundle and held by the priest at a certain point of the sacrifice. Besides the sacred plants the offering comprises small cakes (drana), peculiarly marked, goats' milk (shir), an egg and melted butter (ghee). These are also eaten by the officiating priests in the course of the service.

The true Zoroastrian sacrifice, the Parsees say, is the offering of good thoughts, good words, and good deeds.-Yezd, Persia. (Cat. No. 231789, U.S.N.M.) Gift of A. V. Williams Jackson.

5. Offering tray.-Brass, nickel-plated. Used in the service of the Afringans, which are prayers from the Khorda-Avesta (see above, p. 3) recited only by priests. They are recited on a carpet spread on the floor on which are placed, either in a metal tray or on plantain 
leaves, the choicest fruits and the most fragrant flowers of the season, and glasses filled with fresh milk, pure water, wine, or sherbet. These prayers are recited either with the object of expressing remem. brance of the souls of the departed or with that of invoking the help of the protecting spirits. Diameter, $17 \frac{3}{4}$ inches; depth, $1 \frac{1}{2}$ inches.Bombay, India. (Plate 3, Cat. No. 216054, U.S.N.M.)

6. Offering tray.-Brass, nickel-plated. Similar to the preceding, No. 5, only smaller in size. Diameter, $12 \frac{1}{2}$ inches; depth, $1 \frac{5}{8}$ inches.Bombay, India. (Cat. No. 216055, U.S.N.M.)

7. Sudra--Every Parsee-male or female, priest or layman-must be invested between the ages of seven and fifteen with two articles of dress, called sudra (Avesta, anabdata) and the Kusti (Avesta, aiwyaonghanem). The former is an undershirt of muslin, linen or gauze and is worn next to the skin; the latter is a girdle made up of seventy-two threads of white wool, representing the seventy-two chapters (has) of the Parsee scriptures, in the sacredness of which the neophyte is figuratively bound. The investiture with these two sacred garments, called Navaot, which somewhat corresponds to the Christian ceremony of Confirmation, takes place under elaborate solemn ceremonies and is the first important religious ceremony performed over a Parsee child, consists of two parts: the Nahan and the Navzot proper. The nahan is the religious ablution. The candidate is made to sit on three or more stones either in a temple or on the ground floor of the house and is washed by the priest with consecrated urine of bulls (nirang) ${ }^{12}$ and holy water, while reciting certain holy texts. When the washing is done, the candidate is dressed in a pair of trousers and cap with a white clean linen sheet wrapped round the upper part of the body. He or she is then conducted into the room where the navzot proper is to be performed. The candidate is made to sit on a flat stool facing the east, the emblem of light. The officiating priests take their place on a rich carpet spread on the floor, while the guests sit around on chairs. A fire is kept burning with sandalwood, frankincense, and other pure fragrant substances. The priests as well as the candidate recite the Patet, that is, the confession of sins and repentance. After this the candidate is required to hold the sudra with both hands, and the chief priest, placing his own upon them, causes the candidate to recite the Zoroastrian confession of faith (Kalma-i-din) : "Most true, full of wisdom and good is the religion which God has sent through Zoroaster to this world. This is the religion of Ahura-Mazda brought to man by Zoroaster." Then with the recitation of certain holy texts the chief priest removes the linen sheet and puts in its place the sudra. The

12 Bull's or cow's urine was thought to possess great purifying and medicinal qualities and an antiseptic for demonic infection. It is called in the Avesta gaomeza, Pahlavi and Persian, gomez, and when consecrated by special prayers, nirang. 
chief priest then passes the kusti round the child's waist three times, to remind the wearer of the three cardinal virtues of the Zoroastrian religion, namely, good thoughts, good words, and good deeds, and ties it with four knots, two in front and two behind while chanting a short hymn. At the first knot he says, "There is only one God, and no other is to be compared with him." At the second, "The religion given by Zoroaster is true." At the third, "Zoroaster is the true prophet, who derived his mission from God." And the fourth, "Perform good actions, and abstain from evil ones." After this the candidate is reseated on the stool and the chief priest delivers the Hosban, a short sermon in praise of honesty, truth, and purity. This over, he pronounces blessings upon the candidate, throwing over his or her head small pieces of dry fruits, such as cocoanuts, almonds, raisins, rice, etc.

The investiture with the sudra and kusti initiates one into full membership of the Zoroastrian community, entitling to being present in all religious ceremonies and assemblies. And after having undergone the navzot ceremony the Zoroastrian has to put on the sudra and kusti day and night; the performance of any function of life without wearing these two sacred articles of dress is considered a. sin, called "Running uncovered with sudra and kusti." The ceremony of untying and retying the kusti (padyab kusti), reciting a short prayer during the process, has to be performed several times in the day; for instance, early in the morning on rising from bed, before prayers, before meals, after ablutions, etc.

If a child die before the performance of the ceremony of navzot, he is considered to have gone back to Ahura-Mazda, who gave him, as pure as he entered this world, having not reached the age of accountability.-Bombay, India. (Plate 4, showing the ceremony of investiture with the sudra and kusti, Cat. No. 230800, U.S.N.M.) Gift of Rastamji Edulji Dastoor Peshotan Sanjana, Deputy High Priest of the Parsees, Bombay, India.

8. Costume of a Parsee.-It consists of the sudra and kusti (see under the preceding, No. 7), loose cotton trousers, an ample doublebreasted coat of cotton, reaching to the ankles, called jama; a belt, called pichori, made of cotton, about 1 yard wide and several yards in length, which is folded once and passed round the waist as many times as its length will admit; a pair of cotton gloves; a skullcap of cotton; and a turban peculiar to the Parsees. It is made of figured chocolate-colored silk, stiffened, without any rim, and has an angle from the top of the forehead. This costume is only used on formal and solemn occasions.

The dress of the priests is the same only that it is made solely of white cotton cloth, including the turban.-Bombay, India. 5, Cat. No. 216056, U.S.N.M.)

(Plate 
9. Suit of a Parsee schoolgirl.-It consists of the sudra and kusti (for which see under No. 7) ; trousers of blue silk, richly embroidered; white silk waist, embroidered in various colors; skullcap of cotton ; $^{13}$ and a flat, rimless hat, adorned all over with silver embroidery.Bombay, India. (Plate 6, showing a Parsee family, Cat. No. 4009, U.S.N.M.)

10. Tower of silence (Dakhma).-Model of wood, painted. The rules of clean and unclean and the purifications necessary to repair witting or unwitting infractions of them constitute a large part of practical religion of Zoroastrianism. It is the outcome of the belief that the elements, fire, water, earth, and air are the creations and sublime gifts of Ahura-Mazda, and that on the preservation of their purity depended the weal and welfare of the world. Uncleanliness in the religious sense is considered a demonic contagion, and the sphere in which the presence and agency of demons is most clearly seen is death, and here the greatest precautions must be taken. Inexpiable is the sin that one commits by bringing a corps, a carcass, or any impure object in contact with the elements. If a corpse be found in the water of a well, a pond, or running stream, the water is not fit to drink until the corpse is removed and a great part of the well or stream is drawn off. A field in which a dead body is found lying must remain fallow for a year. The ground in which a body has been buried is unfit for agriculture for fifty years. Even if a man lets fall and remain on earth a bone, a nail, hair, or any like thing he commits a grievous sin. The Parsees, accordingly, neither burn or bury their dead nor consign them to water, but expose them on mountain heights upon the so-called towers of silence (dakhmas) to be consumed by vultures.

The dakhma is a circular structure of stone, from 60 to 90 feet in diameter and from 20 to 30 feet in height, open at the top and resembling a gasometer. Inside is a circular platform paved with large stone slabs, called pavis, upon which the dead bodies are laid. The pavis are ranged in three concentric rows, the outer being for men, the middle for women, and the inner for children. The pavis are separate from each other by ridges, called dandas, which are about an inch in height above the level of the pavis, and channels are cut into the pavis for the purpose of conveying all the liquid matter flowing from the corpse and rainwater into the pit. The "heaven-sent birds," which are always in the vicinity, swoop down upon the corpse as soon as it is exposed, and it is said that it is quite stripped of flesh in an hour or two. In the center of the platform is a pit (bhandar) about 30 feet in diameter, from which four drains lead into four wells sunk in the ground outside of the tower. Into this pit the

13 The Parsees consider it sinful to leave the head uncovered either by day or nigh! hence neither a man nor a female is ever without some head covering. 
denuded bones are later deposited where they, under the tropical sun, crumble into dust and are then with all other remaining matter conducted through the drains to the wells. The drains are provided with disinfectants (charcoal and sandstone) to purify the matter before it enters the ground so as to preserve the earth from defilement.

When death is near, a priest is called in who recites the confession of $\sin$ (patet) and sundry passages from the Avesta which afford consolation to the dying person. If he is in possession of his senses he himself joins in these exercises; if not, the words are repeated in his ears. The priest puts into his mouth some drops of the haoma juice (see above under No. 4) as a last sacrament. When life becomes extinct the body is cleaned by first sprinkling a few drops of nirang (for which see note to No. 7) and then washing whole with pure water. It is then laid out on the ground on which a clean sheet of cotton has been spread out, and wrapped in clean clothes, which must be old and worn, in order to admit of ready destruction. From that time none is allowed to touch the corpse except the professional carriers of the dead (nasasalars). Two priests standing side by side, holding a cord or piece of cloth, called the paivand, between their hands, recite the funeral service, called Gahan-savayashni, which consists of seven chapters of the first Gatha of Zoroaster (see above, p. 3). A dog-if possible, one with "four eyes," that is, with spots of light color above the eyes, or a white dog with yellow ears-is brought into the chamber in which the body is laid out. This ceremony is called Sagdid "glance of the dog," and is repeated several times, for the glance of the dog is a terror to demons. Fire also is brought into the room and is fed with fragrant materials, such as sandalwood, frankincense, etc., the odor of which kills the demons wherever the wind carries it. At the close of the funeral service the corpse bearers having purified themselves, put on white clothes and perform the kusti ceremony (see above under No. 7 ), place the body upon an iron bier, called Gehan, and the funeral procession sets out. This must take place in daytime, for it is essential that the body should be exposed to the sun, and the corpse-devouring birds be present at the tower. The body is covered with a white shroud and secured to the bier with pieces of cloth. Four of the corpse bearers lift the bier on their shoulders and walk toward the tower of silence. They are followed by the funeral procession, headed by priests. All in the procession walk two and two, joined with paivand and reciting prayers. When the procession reaches the tower the bier is put on the ground and the face of the deceased is uncovered. All those who are present take a last look at the deceased, bowing and standing at a distance of three paces. The last sagdid is performed and the bier is carried by two nasasalars into the tower, who, removing the body from it, place it wholly uncovered on one of the pavis. The clothes 
which were removed from the body are thrown into a deep pit outside the tower, which is purposely made to receive them, and left to decompose by heat, air, and rain. All the participants recite a last prayer, undergo a religious purification, washing their faces, hands, and feet with nirang and water, and perform the kusti ceremony. The nasasalars have to remain in segregation and pass through the Navshabeh Barashnum purification which lasts nine days and nine nights.

Religious services for the benefit of the deceased are kept up for three days, during which, in the Parsee belief, the soul remains in this world (see above, p. 7). The prayers, recited by a priest before a burning fire fed with fragrant substance, are especially directed to Sraosha, the guide and protector of the souls. On the fourth day, on which the soul confronts the judgment at the chinvat bridge, the Uthama ceremony is performed, when after the service the relatives of the deceased, if rich, give sums of money for charitable purposes, feed the poor, and give presents to the priests. During this time the mourners are required to abstain from every kind of flesh. The female relatives sit on a carpet spread on the floor near the spot where the dead body had lain and receive visits from their female friends and connections. No food is prepared in the house before the removal of the corpse, in some families not for the three subsequent days, it being provided for them by relatives and friends. ${ }^{14}$

The principal towers of silence in use at present by the Parsees are on Malabar Hill, at Bombay, India. Height, $17 \frac{1}{2}$ inches; diameter, 28 inches; length of the platform, 48 inches; width, 40 inches.Bombay, India. (Plate 7, Cat. No. 215412, U.S.N.M.)

11. Tower of silence (Dakhma).-Model of wood, painted. Similar to the preceding, No. 10. Height, 103 inches; diameter, 29 inches; length of base, 40 inches; width, $39 \frac{1}{4}$ inches.-Bombay, India. (Cat. No. 301554, U.S.N.M.) Presented to the Library of Congress in Washington, D. C., by Romonjee Dinshaw Petit in March, 1892, and transferred by the Library of Congress to the United States National Museum.

14 Among orthodox Jews a mourner, both male and female, for a near relative-father or mother, son or daughter, brother or sister, wife or husband-is confined to the house for seven days (hence the mourning is called Shib'ah, that is, seven), in which he sits on the floor in stocking feet and has to refrain from manual labor or business transactions. The first meal after the funeral is prepared by a neighbor. 


\section{$2 \mathrm{BHL}$ Biodiversity Heritage Library}

Casanowicz, Immanuel Moses. 1922. "Parsee religious ceremonial objects in the United States National Museum." Proceedings of the United States National Museum 61(2432), 1-16. https://doi.org/10.5479/si.00963801.61-2432.1.

View This Item Online: https://www.biodiversitylibrary.org/item/31797

DOI: https://doi.org/10.5479/si.00963801.61-2432.1

Permalink: https://www.biodiversitylibrary.org/partpdf/20197.

\section{Holding Institution}

Smithsonian Libraries

\section{Sponsored by}

Smithsonian

\section{Copyright \& Reuse}

Copyright Status: NOT_IN_COPYRIGHT

This document was created from content at the Biodiversity Heritage Library, the world's largest open access digital library for biodiversity literature and archives. Visit BHL at https://www.biodiversitylibrary.org. 